\title{
SINTESIS DAN KARAKTERISASI HIDROKSIAPATIT DARI \\ CANGKANG KERANG DARAH (Anadara granosa) \\ SEBAGAI BAHAN BAKU SEMEN \\ TAMBAL GIGI
}

\author{
Rahmaniah \\ Jurusan Fisika UIN Alauddin Makassar \\ E-mail: nia.physics08.uin@gmail.com
}

\begin{abstract}
Abstrak: Hidroksiapatit (HAp) merupakan senyawa mineral apatit. HAp merupakan senyawa yang memiliki kemiripan dengan bagian mineral dalam tulang. Pemanfaatan hidroksiapatit dalam bidang medis khususnya dalam bidang kedokteran gigi terus dikembangkan dalam berbagai penelitian, salah satu contohnya adalah pemanfaatan hidroksiapatit dari cangkang kerang darah sebagai semen tambal gigi. Tujuan penelitian ini adalah mengetahui struktur kristal, ukuran butiran dan sifat mekanik hidroksiapatit dari cangkang kerang darah. Metode yang digunakan dalam penelitian ini adalah metode eksperimen dengan menggunakan alat uji XRD untuk mengetahui struktur dan ukuran butiran krital sedangkan alat Universal Testing Mechine (UTM) digunakan untuk mengetahui kuat tekan sampel. Hasil penelitian menunjukkan struktur kristal yang dihasilkan dari sintesis hidroksiapatit cangkang kerang darah adalah aragonite dengan rata-rata ukuran kristal yang dihasilkan sebesar 5,87 $\mathrm{nm}$. Sedangkan nilai kuat tekan yang terbesar diperoleh pada sampel 2 yaitu 9,521 MPa, sedangkan nilai kuat tekan yang terkecil yaitu pada sampel 1 sebesar 3,51 MPa.
\end{abstract}

Kata Kunci: Cangkang kerang darah, Hidroksiapatit, UTM, XRD

\section{PENDAHULUAN}

$\mathrm{M}$ ineral utama penyusun tulang dan gigi adalah garam kalsium fosfat atau $\mathrm{CaP}$. Kalsium fosfat yang paling stabil terdapat dalam hidroksiapatit. Hidroksiapatit atau disingkat dengan HAp merupakan senyawa mineral apatit. HAp merupakan senyawa yang memiliki kemiripan dengan bagian mineral dalam tulang. HAp memiliki struktur Kristal monoklinik maupun heksagonal. Pemanfaatan hidroksiapatit dalam bidang medis khususnya dalam bidang kedokteran gigi terus dikembangkan dalam berbagai penelitian, salah satu contohnya adalah pemanfaatan hidroksiapatit dari cangkang kerang darah sebagai semen tambal gigi.

Salah satu material yang dapat diolah menjadi Biomaterial adalah cangkang kerang darah. Cangkang kerang darah (Anadara granosa) tinggi akan kalsium yang dapat menguatkan gigi dan tulang, dimana cangkang kerang darah mengandung Kalsium Oksida $(\mathrm{CaO}) 66.70 \%$, Silika $\left(\mathrm{SiO}_{2}\right) 7.88 \%$, Aluminium Oksida $\left(\mathrm{Al}_{2} \mathrm{O}_{3}\right) 1.25$ $\%$, Ferri Oksida $\left(\mathrm{Fe}_{2} \mathrm{O}_{3}\right) 0.03 \%$, dan Magnesium Oksida $(\mathrm{MgO}) 22.28 \%$. Pemanfaatan limbah cangkang kerang darah yaitu dapat dijadikan sebagai bahan pengganti semen karena memiliki kandungan zat kapur yang sangat banyak. Selain itu cangkang kerang 
darah dapat dimanfaatkan dalam sintesis nano hidoksiapatit sebagai bone implan untuk kerusakan tulang karena cangkang kerang memiliki kandungan kalsium yang sangat tinggi yaitu sebesar $66,70 \%$ dan tulang memerlukan kalsium yang banyak untuk pergerakannya.

Berdasarkan uraian di atas, maka penulis tertarik untuk melakukan penelitian tentang pemanfaatan limbah cangkang kerang sebagai bahan alternatif dalam pembuatan komponen powder sebagai bahan baku pembuatan semen tambal gigi.

\section{METODELOGI PENELITIAN}

\section{A. Jenis Penelitian}

Penelitian ini merupakan penelitian terapan yang bertujuan untuk meningkatkan pengetahuan ilmiah dengan suatu tujuan praktis, yang mana hasilnya diharapkan dapat dimanfaatkan dengan tujuan praktis pula. Metode yang digunakan dalam penelitian ini adalah metode eksperimen yang bertujuan untuk mencari pengaruh variabel ukuran butiran, temperatur dan komposisi sampel. Eksperimen dilakukan di laboratorium dua tempat yakni laboratorium Fisika dasar UINAM dan Science Building di UNHAS.

\section{B. Alat dan bahan}

Bahan yang digunakan dalam penelitian ini adalah limbah cangkang kerang darah yang dimanfaatkan sebagai sumber kalsium, $\left(\mathrm{NH}_{4}\right)_{2} \mathrm{HPO}_{4}$ sebagai sumber fosfat, $\mathrm{NH}_{4} \mathrm{OH}$ sebagai pengatur $\mathrm{PH}$, dan akuades sebagai pelarut.

\section{Prosedur Penelitian}

\section{a) Pembuatan bahan baku}

Pembuatan bahan baku powder cangkang kerang darah dilakukan dengan cara cangkang kerang darah dibersihkan terlebih dahulu dan dijemur satu hari untuk menghilangkan kadar air pada proses pembersihan. Cangkang kerang darah yang telah kering dihaluskan menggunakan lumpang dan diayak menggunakan ayakan 200 mesh. Selanjutnya sampel dikalsinasi pada suhu $800{ }^{\circ} \mathrm{C}$ selama 5 jam untuk mendapatkan $\mathrm{CaCO} 3$ menjadi $\mathrm{CaO}$.

\section{b) Sintesis Hidroksiapatit}

Sintesis hidroksiapatit dilakukan dengan mencampurkan serbuk cangkang kerang yang sudah dikalsinasi dengan (NH4)2HPO4. NH4OH digunakan untuk meningkatkan $\mathrm{pH}$ campuran hingga 12. Proses pencampuran ini menggunakan pelarut akuades dan dilakukan di dalam vessel hidrotermal. Kemudian vessel dimasukkan ke dalam oven dengan suhu reaksi $180{ }^{\circ} \mathrm{C}$ selama 20 jam. Hasil yang didapat kemudian dicuci dengan menggunakan akuades, kemudian sampel dikeringkan hingga beratnya konstan.

\section{c) Karakterisasi Produk}

1. Analisis XRD

Karakterisasi produk bubuk cangkang kerang darah yang telah disintesis dianalisis dengan menggunakan alat uji $\mathrm{X}$ ray Difraction (XRD). Tujuannya untuk mengetahui struktur dan ukuran butiran Kristal produk bubuk cangkang kerang darah yang telah disintesis.

2. Analisis Kuat tekan

Bubuk cangkang kerang darah yang telah disintesis selanjutnya dicampur 
dengan cairan asam poliakrilik, setelah homogeny campuran tersebut dicetak dengan menggunakan pipet sedotan minuman berdiameter $4 \mathrm{~mm}$ dan 8,50 mm dengan tinggi $6 \mathrm{~mm}$ dan $10 \mathrm{~mm}$, selanjutnya didiamkan sampai mengeras selama 24 jam. Sampel yang telah dilepakan dari cetakan selanjutnya dikeringkan dibawah sinar matahari selama tiga hari. Kemudian sampel diuji nilai tekanannya dengan menggunakan alat uji Universal Testing Mechine dengan beban $20 \mathrm{kN}$.

\section{HASIL DAN PEMBAHASAN}

\section{Karakterisasi XRD}

Pola karakterisasi $x$ Ray Difraction cangkang kerang darah dapat dilihat pada gambar berikut:

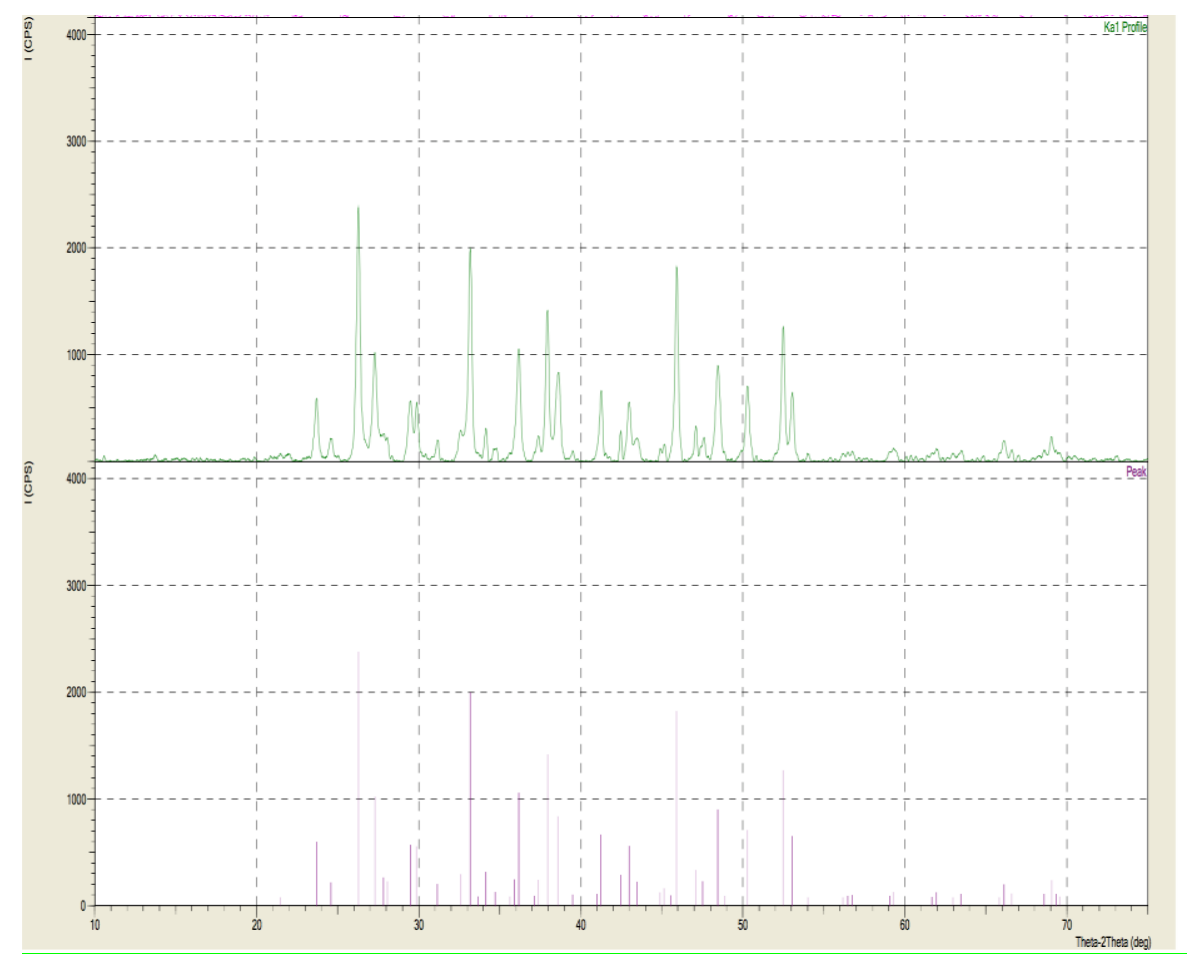

Gambar 1 Pola Difraksi dari Hidroksiapatit

Tabel 1. Hasil Pengukuran Intensitas dan 2 Theta yang terbentuk

\begin{tabular}{lccccccc}
\hline No & Peak & $2 \theta$ & $\begin{array}{c}\mathrm{d} \\
(\mathrm{A})\end{array}$ & $\mathrm{I} / \mathrm{I}_{1}$ & FWHM & $\begin{array}{c}\text { Intensitas } \\
\text { (count) }\end{array}$ & $\begin{array}{c}\text { Integrated int } \\
\text { (count) }\end{array}$ \\
\hline 1 & 4 & 26,2724 & 3,38941 & 100 & 0,25980 & 1425 & 22470 \\
\hline 2 & 12 & 33.1785 & 2,69799 & 84 & 0,24310 & 1195 & 15874 \\
\hline 3 & 32 & 45.9211 & 1.97464 & 77 & 0,22980 & 1092 & 14164 \\
\hline
\end{tabular}


Tabel 2. Analisis ukuran butiran Kristal

\begin{tabular}{|c|c|c|c|c|c|c|c|c|c|}
\hline $\begin{array}{l}\text { Kode } \\
\text { Sampel }\end{array}$ & peak & $2 \theta\left(^{\circ}\right)$ & $\theta$ & $\operatorname{Cos} \theta$ & $\mathrm{K}$ & $\begin{array}{c}\lambda(\AA= \\
10^{-10} \\
\mathrm{~m})\end{array}$ & $\beta$ & $\mathrm{L}(\mathrm{nm})$ & $\begin{array}{c}\text { Rata-Rata } \\
\text { Ukuran } \\
\text { Kristal (nm) }\end{array}$ \\
\hline \multirow{7}{*}{$\begin{array}{l}\text { Bubuk } \\
\text { cangkang }\end{array}$} & 1 & 26.2724 & 13.1362 & 0.973832573 & \multirow{7}{*}{0.94} & \multirow{7}{*}{1.5406} & 0.2598 & 5.723929865 & \multirow{7}{*}{5.870233709} \\
\hline & 2 & 33.1785 & 16.58925 & 0.958376159 & & & 0.2431 & 6.215796487 & \\
\hline & 3 & 45.9211 & 22.96055 & 0.920773666 & & & 0.2298 & 6.844076143 & \\
\hline & 4 & 52.4916 & 26.2458 & 0.896905161 & & & 0.2382 & 6.778435488 & \\
\hline & 5 & 27.2882 & 13.6441 & 0.971779726 & & & 0.3107 & 4.796325621 & \\
\hline & 6 & 38.5903 & 19.29515 & 0.943828926 & & & 0.3536 & 4.339225376 & \\
\hline & 7 & 37.9387 & 18.96935 & 0.945692601 & & & 0.2395 & 6.393846979 & \\
\hline
\end{tabular}

Sumber : Data Primer, 2018

\section{Pengukuran Kuat Tekan}

Pengujian kuat tekan terhadap sampel dilakukan dengan menggunakan alat uji Universal Testing Mechine (UTM), berikut hasil pengukuran nilai kuat tekan sampel.

Tabel 3. Nilai kuat tekan semen gigi dengan campuran pasta gigi dan tanpa campuran pasta gigi.

\begin{tabular}{cccc}
\hline No sampel & $\mathrm{A}\left(\mathrm{mm}^{2}\right)$ & $\mathrm{F}(\mathrm{N})$ & $\mathrm{P}(\mathrm{MPa})$ \\
\hline 1 & 25,505 & 89,5 & 3,51 \\
\hline 2 & 15,545 & 148 & 9,521 \\
\hline 3 & 15,545 & 119,5 & 7,687 \\
\hline 4 & 18,086 & 100 & 5,529 \\
\hline 5 & 45,342 & 320 & 7,057 \\
\hline 6 & 42,987 & 240 & 5,583 \\
\hline 7 & 38,465 & 300 & 7,799 \\
\hline 8 & 42,987 & 220 & 5,118
\end{tabular}

\section{Diskusi Data}

\section{Analisis $X R D$}

Karakterisasi cangkang kerang darah dengan XRD bertujuan untuk mengetahui dan mempelajari struktur kalsium yang terdapat pada cangkang kerang. Karakterisasi XRD ini dilakukan secara kualitatif dengan membandingkan puncak-puncak yang terbentuk dengan pada difraktogram HAp hasil sintesis dengan puncak-puncak pada difraktogram HAp standar dari data JCPDS (Joint Committee on Powder Diffraction Standards) dengan No. 09-432.

Pola difraksi yang diperoleh dari difraktometer menggambarkan status kristalinitas material yang diuji. Pola difraksi yang diperoleh menunjukkan bahwa fasa yang terbentuk dari hidroksiapatit adalah Kristal, hal ini ditandai dengan adanya puncak-puncak difraksi yang terbentuk, seperti yang nampak pada gambar 4.1.

Berdasarkan data analisis XRD Fasa-fasa yang terbentuk diidentifikasi dengan menggunakan data JCPDS 09-432, untuk fasa HAp dicirikan intensitas utama pada nilai $2 \theta$ sebesar 26,$2724 ; 33.1785$; dan 45.9211 . $K$ adalah konstanta untuk material sebesar 0,94 , panjang gelombang $(\lambda)$ yang digunakan pada alat XRD yaitu $0,15406 \mathrm{~nm}$, dan $\beta$ adalah FWHM (Full width at half maximum) dari garis difraksi skala 20. Semakin besar sudut difraksi yang dihasilkan nilai FWHM semakin kecil. Mengecilnya nilai FWHM menyebabkan lattice strain mengecil. Selain itu, lattice strain sama halnya dengan dislocation density yaitu semakin besar lattice strain maka ketidak sempurnaan kisi atau cacat kristal semakin besar (Tabel 4.1).

Struktur kristal menggunakan X-ray Diffraction (XRD) menjelaskan bahwa cangkang kerang darah terdiri dari aragonite. Ini adalah salah satu jenis bentuk kristal 
kalsium karbonat selain calcite dan vaterite. Meskipun calcite adalah bentuk kristal kalsium karbonat paling stabil, aragonit memiliki kepadatan lebih tinggi dan kekerasan yang tinggi.

Berdasarkan hasil data XRD ukuran partikel didapat dengan menghitung FWHM (Full width Half Maximum) dapat ditentukan ukuran partikel menggunakan formula Scherer (Djamas 2010), maka diperoleh nilai rata-rata ukuran partikel sebesar $5.870233709 \mathrm{~nm}$, seperti yang nampak pada tabel 4.2.

\section{Analisis Uji Kuat Tekan}

Tabel 4.3 menunjukan nilai uji kekuatan tekan, nilai kuat tekan terbesar terdapat pada sampel 2 yaitu 9,521 $\mathrm{MPa}$, nilai ini diperoleh dari komposisi limbah cangkang kerang 0,143 gr, 2 tetes cairan asam poliakrilik, dan campuran pasta gigi sebanyak $2 \%$ Sedangkan Nilai kekuatan tekan yang terendah yaitu pada sampel 1 dengan komposisi limbah cangkang kerang darah $0,143 \mathrm{~g}$ dan 2 tetes cairan asam poliakrilik adalah 3,51 MPa.

Menurut standar untuk dental semen gigi ANSI/ADA No.96 (ISO 9917) nilai Compressive strength 24 jam semen ionomer kaca berkisar dari 90 hingga $230 \mathrm{MPa}$. Nilai uji kekuatan tekan dari sampel bubuk cangkang kerang darah yang telah dibuat belum memenuhi standar yang ada. Namun jika dibandingkan dengan beberapa hasil penelitian yang telah dilakukan sebelumnya sebagaimana dituliskan pada bab II, nilai kekuatan tekan yang dihasilkan masih jauh lebih besar.

Hasil uji tekan yang diperoleh belum memenuhi standar, hal ini disebabkan karena beberapa faktor selama penelitian dilakukan diantaranya yaitu cetakan terbuat dari pipet plastik yang elastis menyebabkan bentuk sampel silinder tidak sempurna, volume cetakan tidak seragam hal ini dikarenakan pada saat pencampuran bubuk dan cairan yang berbeda-beda, jarak pemberian cairan diatas bubuk tidak semua sama sehingga hasil cetakan sampel tidak homogen dengan baik dan tidak berbentuk silinder dengan sempurna.

\section{PENUTUP}

\section{A. Kesimpulan}

Berdasarkan data yang diperoleh maka dapat disimpulkan bahwa :

1. Struktur kristal yang dihasilkan dari sintesis hidroksiapatit cangkang kerang darah adalah aragonite dengan rata-rata ukuran kristal yang dihasilkan sebesar 5,87 nm.

2. Nilai kuat tekan terbesar terdapat pada sampel 2 yaitu 9,521 $\mathrm{MPa}$, sedangkan nilai kuat tekan yang terkecil yaitu pada sampel 1 sebesar 3,51 MPa.

\section{B. Saran}

Setelah melakukan penelitian ini maka saran yang dapat diberikan untuk penelitian selanjutnya adalah sebaiknya dibuatkan ukuran cetakan yang standar dan diuji lebih lanjut sifat biokompatibilitas.

\section{DAFTAR PUSTAKA}

Bertenshaw BW and Combe EC. (1973). Studies on Polycarboxylate and Related Cement, I. Analysis of Cement Liquids. J, Prosbed Dent, 29(217). 
Cerruti MG. (2004). Characterization of bioactive glasses. Effect of the immersion in solutions that simulated body fluids. [thesis]. PhD in Chemical Science 2001-2004. University of Turin. Italy.

Coleman N.J. and Nicholson J.W. (2006) Inorganic glasses and ceramics for bone tissue engineering. Education in Chemistry, 43(2006), 156-160.

Cotton, F. Albnert and Wilkinson, Geoffrey. (1976). Basic Inorganic Chemistry. John Willey \& son, Inc.

David L. Heisman. (2005). Fundamentals of Dental Materials. Sweet Haven Publishing Series.

Davidson CL dan Mjor IA. (1999). Advances in Glass Ionomer Cement. Chicago Quintessence. 15(46), 121-33.

De Moor RJG dan Verbeeck RMH. (1998). Effect of acetic acid on the fluoride release profiles of restorative Glass Ionomer cement. Dental Material, 14, 261-8.

Emre B. (2007). Biocompatibility of Retrograde root filling materials : a Review. Aust. Endo. Journal, 34(1), 30-35.

Fan Y, Lu X. (2008). A study of apatite formation on natural nano-hydroxyapatite/chitosan composite in simulated body fluid. Fr. Matr. Sci. Ch., 2(1), 91-4.

Frankenberger R, Sindel J dan Kramer N. (1997). Viscous Glass Ionomer cements; A new alternative to amalgam in primary dentition. Quint Int., 28(10), 667-75.

Ghufran, M. (2011). Budidaya 22 Komoditas Laut untuk Konsumsi Lokal dan Ekspor. Yogyakarta: Lily Publisher.

Greenspan DC. (1999). Development in Biocompatible Glass Compositions.An MD\&DI March 1999. Column, Spec Section. ww.devicelink.cm/mddi/archive/99/03/011.html.

Hatton PV, Hurrel-Gillingham K, Brook IM. (2006). Biocompatibility of Glass Inomer Bone Cements. J Dent 34(2006), 598-601.

Hench LL, Jones JR, Sepulveda P. Bioactive Materials for Tissue Engineering Scaffolds. p3-24.

Hickel RA dan Folwaczny M. (2001). Various Forms of Glass Ionomer and Compomers. J. Op.Dent. 2001(6), 177-90.

John R.Cameron,dkk. (1999). Physics Of The Body, second edition. Medical Physics Publishing.

Kawahara H, Imanishi Y, Oshima H. (1979). Biological Evaluation on Glass Ionomer Cement. J Dent Res. 58(3), 1080-6.

Nicolodi L, Sjölander E, Olsson K. (2004). Biocompatible Ceramics -An Overview of Applications and Novel Material. KTH, Nov(1), 4-12.

Nourmohammadi J, Sadrnezhaad SK. (2008). Bone-like apatite layer formation on the new resinmodified glass-ionomer cement. J Mater Sci: Mater Med 2008(19), 3507-14.

Robert G. Craig and John M. Power. (2002). Restorative Dental Cement, 1th. Ed. Mosby Company.

Romimohtarto, K., dan Juwana, S. (2001). Biologi Laut Ilmu Pengetahuan Tentang Biota Laut. Jakarta: Djambatan.

Schour I. (1960). The structure of enamel. In Lea \& Febiger. Noye's oral histology and embryology (8nd ed.). Philadelphia. 88-113.

Suweto IS. (1995). Penggunaan Bahan Sewarna Gigi Untuk Pencegahan Karies dan Restorasi Gigi Anak. JKGUI, 2(3), 33-9.

Wilson AD dan Mc Leani JW. (1998). Glass Ionomer Cement. Chicago Quentescence Pub. 1998(21-30), 88-98.

Yan Z, Sidhu SK, Carrick TE, McCabe JF. (2007). Response to thermal stimuli of glass ionomer cements. Dental Material. 2007(23), 597-600. 